\title{
Defining Hydrophytes for Wetland Identification and Delineation
}

Ralph W. Tiner

January 2012 


\title{
Defining Hydrophytes for Wetland Identification and Delineation
}

\author{
Ralph W. Tiner
}

U.S. Fish and Wildlife Service

National Wetlands Inventory Program

Northeast Region

300 Westgate Center Drive

Hadley, MA 01035

Approved for public release; distribution is unlimited.

\author{
Prepared for U.S. Army Corps of Engineers \\ Washington, DC 20314-1000 \\ Monitored by Cold Regions Research and Engineering Laboratory \\ U.S. Army Engineer Research and Development Center \\ 72 Lyme Road, Hanover, NH 03755
}




\begin{abstract}
The presence of hydrophytic vegetation is an essential ingredient in the definition of wetlands. The National Technical Committee for Wetland Vegetation was, among other things, charged with reviewing the concept of a hydrophyte and constructing a definition that conforms with the use of hydrophytic vegetation for identifying wetlands, whether regulated or not. This report reviews the term "hydrophyte," presents the proposed definition, and briefly discusses the use of hydrophytes for wetland identification and delineation.
\end{abstract}

DISCLAIMER: The contents of this report are not to be used for advertising, publication, or promotional purposes. Citation of trade names does not constitute an official endorsement or approval of the use of such commercial products. All product names and trademarks cited are the property of their respective owners. The findings of this report are not to be construed as an official Department of the Army position unless so designated by other authorized documents. 


\section{Table of Contents}

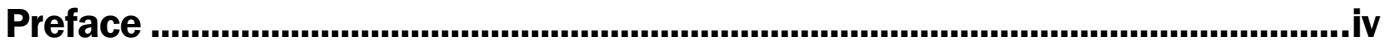

1 Introduction to the Definition of a Hydrophyte............................................... 1

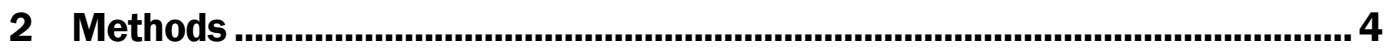

3 Proposed Definition of a Hydrophyte........................................................ 5

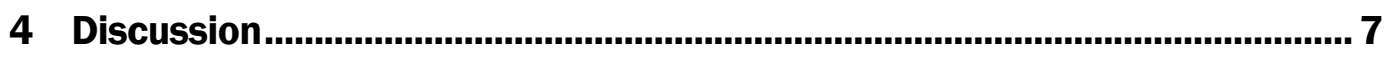

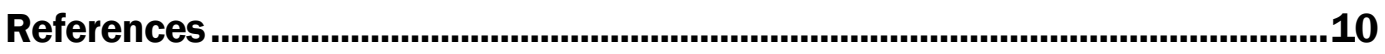

Report Documentation Page 


\section{Preface}

This report was prepared by Ralph W. Tiner, U.S. Fish and Wildlife Service, National Wetlands Inventory Program, in cooperation with the National Technical Committee for Wetland Vegetation (NTCWV). The NTCWV was established in 2007 to provide technical support to the U.S. Army Corps of Engineers in the area of plant ecology to aid in improving techniques used to identify and delineate wetlands. Members of the NTCWV include Robert Lichvar, Paul Minkin, Tina Teed, Paige Wolken, and J im Wiseman (U.S. Army Corps of Engineers); Norman Melvin and Michelle Schuman (U.S. Department of Agriculture Natural Resources Conservation Service); Mary Butterwick and Bill Kruczynski (U.S. Environmental Protection Agency); Ralph Tiner (U.S. Fish and Wildlife Service); David Cooper (University of Colorado); Donald Leopold (State University of New York-Syracuse, College of Environmental Science and Forestry); Lytton Musselman (Old Dominion University); and Hans Williams (Stephen F. Austin State University). Peer review of this report was performed by Robert Lichvar (Director of the National Wetland Plant List, U.S. Army Corps of Engineers), Dr. David Cooper, and Dr. Donald Leopold.

This research was funded by the U.S. Fish and Wildlife Service.

This study was conducted under the general supervision of Robert Lichvar of the Remote Sensing/ Geographic Information Systems (RS/GIS) and Water Resources Branch, Cold Regions Research and Engineering Laboratory (CRREL), U.S. Army Engineer Research and Development Center (ERDC), Hanover, NH; Timothy Pangburn, Chief, RS/ GIS and Water Resources Branch; Dr. J ustin B. Berman, Chief, Research and Engineering Division; Dr. Lance Hansen, Deputy Director; and Dr. Robert E. Davis, Director. Permission to publish was granted by Director, Cold Regions Research and Engineering Laboratory.

COL Kevin J . Wilson was the Commander and Executive Director of ERDC, and Dr. J effery P. Holland was the Director. 


\section{Introduction to the Definition of a Hydrophyte}

Wetlands have commonly been viewed as transitional habitats between land (terrestrial ecosystems) and water (deepwater aquatic systems) because they are often found along rivers, lakes, ponds, and estuaries. Despite this common view, wetlands possess many unique properties that are not shared by adjacent deepwater habitats or dry land. Consequently, they are distinctive ecosystems and not simply hybrids of aquatic and terrestrial ecosystems (Tiner 1993, 1999). Moreover, wetlands can form on slopes or in isolated depressions surrounded by dry land where there is a frequent and sufficient supply of water to saturate the land surface for extended periods. Wetlands therefore occur along the natural soil moisture gradient between permanently flooded deepwater areas and dry land. The fact that many wetlands are not associated with water bodies makes wetland identification more complicated than if they were always associated with a lake, pond, river, stream, or estuary.

Wetland hydrologic conditions range from permanent inundation (shallow water habitats) to periodic soil saturation at or near the soil surface (seasonally waterlogged habitats). Plants that grow and reproduce in wetlands have morphological, physiological, and reproductive adaptations to tolerate excessive wetness (Table 1). The more extreme the wetness, the more highly specialized the adaptations must be for the plant to successfully colonize that environment. Consequently, the most specialized of the wetland plants live in water or in areas of long-term wetness. As soil wetness decreases, many other plants can colonize these wetlands. Plant composition gradually changes to what some might consider a "transitional community" where hydrophytes intermix with mesic (moist soil) species, making wetland identification challenging, particularly if plants are the sole criterion for identification. Early plant ecologists recognized the difficulty of using plants to separate wet habitats from mesic habitats. For example, the Dutch plant ecologist Eugenius Warming (1909) noted that "it is impossible to establish any sharp distinction between swamp-forests and forests on dry land" in some places based on the plants alone. In their classic textbook on plant ecology, Weaver and Clements (1929) commented that "amphibious plants have a wide range of adjustment and may grow for a time as mesophytes or partially submerged." 
Table 1. Plant adaptations or responses to flooding and waterlogging (Tiner 1991, 1999). Some of these features are not exclusive to hydrophytes but may also occur in non-hydrophytes for other reasons.

\begin{tabular}{|c|c|c|}
\hline $\begin{array}{l}\text { Morphological } \\
\text { Adaptations/Responses }\end{array}$ & $\begin{array}{l}\text { Physiological } \\
\text { Adaptations/Responses }\end{array}$ & Other Adaptations/Responses \\
\hline $\begin{array}{l}\text { Stem hypertrophy (e.g., buttressed } \\
\text { tree trunks) } \\
\text { Large air-filled cavities in center } \\
\text { (stele) of roots and stems } \\
\text { Aerenchyma tissue in roots and } \\
\text { other plant parts } \\
\text { Hollow stems } \\
\text { Shallow root systems } \\
\text { Adventitious roots } \\
\text { Pneumatophores (e.g., cypress } \\
\text { knees) } \\
\text { Swollen, loosely packed root } \\
\text { nodules } \\
\text { Lignification and suberization } \\
\text { (thickening) of root } \\
\text { Soil water roots } \\
\text { Succulent roots } \\
\text { Aerial root-tips } \\
\text { Hypertrophied (enlarged) lenticels } \\
\text { Relatively pervious cambium (in } \\
\text { woody species) } \\
\text { Heterophylly (e.g., submerged vs. } \\
\text { emergent leaves on same plant) } \\
\text { Succulent leaves }\end{array}$ & $\begin{array}{l}\text { Transport of air to roots from } \\
\text { lenticels and/or leaves (as often } \\
\text { evidenced by oxidized } \\
\text { rhizospheres) } \\
\text { Anaerobic respiration } \\
\text { Increased ethylene production } \\
\text { Reduction of nitrate to nitrous } \\
\text { oxide and nitrogen gas } \\
\text { Malate production and } \\
\text { accumulation } \\
\text { Reoxidation of NADH } \\
\text { Metabolic adaptations }\end{array}$ & $\begin{array}{l}\text { Seed germination under water } \\
\text { Viviparous seeds } \\
\text { Root regeneration (e.g., } \\
\text { adventitious roots) } \\
\text { Growth dormancy (during flooding) } \\
\text { Elongation of stem or petioles } \\
\text { Root elongation } \\
\text { Additional cell wall structures in } \\
\text { epidermis or cortex } \\
\text { Root mycorrhizae near upper soil } \\
\text { surface } \\
\text { Expansion of coleoptiles (in } \\
\text { grasses) } \\
\text { Change in direction of root or stem } \\
\text { growth (horizontal or upward) } \\
\text { Long-lived seeds } \\
\text { Breaking of dormancy of stem } \\
\text { buds (may produce multiple } \\
\text { stems or trunks) }\end{array}$ \\
\hline
\end{tabular}

The evolution of a term "hydrophyte" has been described (Tiner 1991; Sculthorpe 1967). The term originated in 1822 and was initially applied to plants growing in water (aquatic plants). Over time, plants that grew in saturated or waterlogged soils (formerly called "helophytes") were added to the hydrophyte definition. Weaver and Clements (1929) considered hydrophytes to be plants that "grow in water, in soil covered by water, or in soil that is usually saturated." The renowned North American plant ecologist Rexford Daubenmire (1968) might have been the first to add oxygen-deficient soils to the hydrophyte definition (Table 2). In his earlier publications, he did not include oxygen-deprived soils in the definition but considered hydrophytes to be plants growing in water and on "soils containing a quantity of water that would prove supraoptimal for the average plant" (Daubenmire 1947). He did, however, follow that definition with a statement emphasizing that slow movement of oxygen in these soils produced "a complex of critical conditions with which plants can cope only 
if specialized." Modern definitions of hydrophyte consider plants growing either in water or on periodically saturated or waterlogged soils (aquatic and wetland plants) to be hydrophytes.

Table 2. Recent definitions of "hydrophyte."

\begin{tabular}{|c|c|}
\hline Definition & Source \\
\hline $\begin{array}{l}\text { "Any plant growing in a soil that is at least periodically deficient in } \\
\text { oxygen as a result of excessive water content." }\end{array}$ & $\begin{array}{l}\text { Plant Communities: A Textbook of Plant } \\
\text { Synecology (Daubenmire 1968) }\end{array}$ \\
\hline $\begin{array}{l}\text { "Any plant growing in water or on a substrate that is at least } \\
\text { periodically deficient in oxygen as a result of excessive water } \\
\text { content." }\end{array}$ & $\begin{array}{l}\text { Classification of Wetlands and } \\
\text { Deepwater Habitats of the United } \\
\text { States (Cowardin et al. 1979) }\end{array}$ \\
\hline $\begin{array}{l}\text { "Any macrophyte that grows in water or on a substrate that is at } \\
\text { least periodically deficient in oxygen as a result of excessive water } \\
\text { content; plants typically found in wet habitats." }\end{array}$ & $\begin{array}{l}\text { Corps of Engineers Wetlands } \\
\text { Delineation Manual (Environmental } \\
\text { Laboratory 1987) }\end{array}$ \\
\hline $\begin{array}{l}\text { "Large plants (macrophytes), such as aquatic mosses, liverworts, } \\
\text { non-microscopic algae and vascular plants, that grow in } \\
\text { permanent water or on a substrate that is at least periodically } \\
\text { deficient of oxygen as a result of excessive water content. This } \\
\text { term includes both aquatic plants and wetland plants." }\end{array}$ & $\begin{array}{l}\text { Wetland Identification and Delineation } \\
\text { Manual (Sipple 1988) }\end{array}$ \\
\hline $\begin{array}{l}\text { "An individual plant adapted for life in water or periodically flooded } \\
\text { and/or saturated soils (hydric soils) and growing in wetlands and } \\
\text { deepwater habitats; may represent the entire population of a } \\
\text { species or only a subset of individuals so adapted." }\end{array}$ & $\begin{array}{l}\text { Field Guide to Nontidal Wetland } \\
\text { Identification (Tiner 1988) }\end{array}$ \\
\hline $\begin{array}{l}\text { "Any macrophyte that grows in water or on a substrate that is at } \\
\text { least periodically deficient in oxygen as a result of excessive water } \\
\text { content; plants typically found in wetlands and other aquatic } \\
\text { habitats." }\end{array}$ & $\begin{array}{l}\text { Federal Manual for Identifying and } \\
\text { Delineating Jurisdictional Wetlands } \\
\text { (Federal Interagency Committee for } \\
\text { Wetland Delineation 1989) }\end{array}$ \\
\hline
\end{tabular}

Recent advances in wetland delineation practices warranted further examination of the contemporary hydrophyte definition by the National Technical Committee for Wetland Vegetation (NTCWV). This committee was established to provide scientific guidance on the use of plants for identifying and delineating wetlands for the U.S. Army Corps of Engineers regulatory program. The technical guidance for identifying federally regulated wetlands typically requires finding indicators of three factors (i.e., hydrophytic vegetation, hydric soils, and wetland hydrology) to verify the presence of wetlands (Regional supplements to the Corps of Engineers Wetlands Delineation Manual, e.g., USACE 2010). Consequently, the presence of hydrophytes or hydrophytic vegetation is one of the three essential factors for identifying and delineating wetlands subject to the Rivers and Harbors Act and the Clean Water Act. In updating the 1987 Corps wetland delineation manual (Environmental Laboratory 1987), the Corps requested that the NTCWV review the definition of hydrophyte. 


\section{Methods}

The definition of the term "hydrophyte" that was published in the Corps wetland delineation manual is:

"Any macrophyte that grows in water or on a substrate that is at least periodically deficient in oxygen as a result of excessive water content; plants typically found in wet habitats" (Environmental Laboratory 1987).

The NTCWV reviewed several other hydrophyte definitions reported in a summary paper on the topic (Tiner 1991) (Table 2). After reviewing these definitions, the committee discussed the differences among these definitions and considered the strengths and weaknesses of each. During the deliberations, several definitions were proposed that stressed the ability of the species to survive, grow, and reproduce under prolonged wet conditions. Based on these discussions, the NTCWV proposed a new definition that incorporates elements important for identifying hydrophytic vegetation for wetland delineation. 


\title{
3 Proposed Definition of a Hydrophyte
}

\author{
Most of the existing technical definitions were modifications of \\ Daubenmire's definition (Table 2). The NTCWV felt that those definitions \\ did not fully express the requirement for repeated long-term wetness that \\ profoundly influences plant colonization and community composition of \\ wetlands.
}

The NTCWV proposed the following definition:

"Hydrophytes grow in water or on a substrate that is
saturated at a frequency and duration during the
growing period sufficient to affect plant occurrence."

This definition emphasizes that the plant must be growing during a time in which the area is saturated or flooded. The frequency and duration of excessive wetness are important attributes, as these conditions are largely responsible for preventing non-adapted plants from permanently occupying wetlands. This definition excludes species that only colonize wetlands during dry conditions and cannot tolerate the prolonged saturation or flooding typical of wetlands. While such species may occur in wetlands, their existence is ephemeral as they can only survive while drier conditions persist. Resumption of "normal" wetness (i.e., the climatic average) should eliminate these species.

Hydrophytes, therefore, have specialized morphological, physiological, or other adaptations for living, growing, and reproducing in water or substrates that are subject to frequent and prolonged saturation near the surface. Some hydrophytes may not reproduce when the substrate is saturated at or near the surface, but instead delay flowering and fruiting until later in the year when water tables are not at the surface. This is one reproductive adaptation for plants living in wetlands. They do, however, grow when the substrate is waterlogged.

"Growing period" was used instead of "growing season" because growing season has varied meanings. Its typical usage relates to when one should plant agricultural crops or ornamental plants and as such is not 
particularly relevant for defining the period of growth for native species (Malone and Williams 2010; Tiner 1999).

Anaerobic conditions were purposely not included in the definition. The NTCWV recognized that there are hydrophytic plants growing in wellaerated, permanent water.

Finally, the definition refers to substrates and not soils. The term "substrates" is more inclusive, and plants growing on non-soils such as rocks or in riverwash (e.g., gravel) under wetland hydrologic conditions should also be considered hydrophytes. 


\section{Discussion}

The proposed concept of hydrophyte recognizes that species growing in wetlands must have one or more adaptations to survive and reproduce in areas subject to excessive wetness and often accompanying anaerobic conditions. It therefore recognizes the existence of ecotypes of certain species that have the necessary adaptations for life in saturated soils and does not rely strictly on the Linnaean species level of classification to separate hydrophytes from non-hydrophytes. This interpretation is consistent with the conclusion reached by Swiss plant sociologist BraunBlanquet (1932), who said that, although the species taxon has been regarded as conspicuous indicators of certain conditions of life, the "most exact indicators are often, indeed, not the 'good Linnaean species' but rather the elementary species or races, the 'ecotypes' of Turesson." Modern plant ecologists also acknowledge the limitations of using species as unequivocal indicators of environmental conditions:

Plant ecologists would like to use species as deductive tools, as rather precise indicators of certain levels of environmental factors. This may not be a realistic objective for two reasons. First, plants respond to a complex of climatic, edaphic, and biotic factors, and the impact of single factors is difficult to isolate. Second, taxonomic species, whether recognized on morphological, biological, or statistical grounds, are partially artifacts of the human desire to classify (Terrestrial Plant Ecology, Barbour et al. 1980).

The federal government has prepared lists of plants that occur in the nation's wetlands (Reed 1988). Plant species on the list are those "that have demonstrated an ability (presumably because of morphological and/ or physiological adaptations and/ or reproductive strategies) to achieve maturity and reproduce in an environment where all or portions of the soil within the root zone become, periodically or continuously, saturated or inundated during the growing season." Species were further categorized by "wetland indicator status." Five indicator statuses were recognized across the country: obligate wetland (almost always occurs in wetlands; OBL), facultative wetland (usually occurs in wetlands, but 
occasionally found in non-wetlands; FACW), facultative (equally likely to occur in wetlands and non-wetlands; FAC), facultative upland (occasionally found in wetlands, but usually occurs in non-wetlands; FACU), and obligate upland (almost always occurs in non-wetlands; UPL). All species with the exception of obligate upland species have some portion of their populations with adaptations for life in wetlands and occur more than rarely in wetlands. The creation of this list and the current revision of the National Wetland Plant List (Lichvar and Kartesz 2009; http://geo.usace.army.mil/wetland_plants/index.html) have made it possible to gain better perspective on the likelihood of a given plant community being a wetland plant community. Clearly, the OBL species are hydrophytes, while the facultative types contain various proportions of their populations that have the necessary adaptations and occurrences in wetlands to be considered hydrophytes (Tiner 2006).

Over the past 50 years, the use of plant species to identify wetlands has evolved from an approach in which vegetation (plant species) was the chief determinant of wetlands and their boundaries (e.g., original state wetland laws in the 1960s and early 1970s) to the current approach in which vegetation is used in concert with soil and hydrologic characteristics to identify and delineate wetlands (e.g., the federal method). The former approach may still be useful for identifying the wetter wetlands (e.g., salt marshes, inland marshes, shrub bogs, alkaline fens, mangrove swamps, and cypress- tupelo swamps) and where sharp topographic breaks occur, but a more broad-based approach is required to accurately define the limits of the variety of wetlands found throughout the United States along the soil moisture gradient. The existence of wetland ecotypes of FAC and FACU species lacking distinguishing morphological characteristics to separate them from the typical species and the broad ecological amplitude or wide wetness tolerance of many species (e.g., FAC species) make it difficult to rely solely on plant community composition to identify many wetlands and delineate their boundaries. Consequently, evaluation of soil properties and hydrologic characteristics is essential to accurate identification and delineation of wetlands. In the early days of wetland regulation, state government regulators were more willing to rely solely on vegetation to identify wetlands, perhaps because certain wetlands are well expressed by their vegetation, which eventually led to the common misconception that a predominance of "wetland plants" would always result in an accurate wetland delineation and because most wetland 
regulators lacked knowledge of hydric soil properties and their strong correlation with flooded or saturated soil conditions (Tiner 1991).

While the refined definition of hydrophyte clarifies its meaning, the use of plants as indicators of hydrophytic vegetation has been and is being addressed through regional wetland supplements. For this purpose, plant communities dominated by OBL, FACW, and FAC species are considered hydrophytic. The adjective "hydrophytic" implies that the community may consist of hydrophytes based on a simple assessment of the species present. In the case of FACW and FAC types, the presence of hydrophytes and wetland must be proven by verifying the presence of hydric soil and wetland hydrology indicators. For communities dominated by OBL species, only evidence of wetland hydrology needs to be confirmed for a wetland determination, given that these species are virtually exclusive to wetlands. While FACU species are generally regarded as non-hydrophytes, the regional wetland supplements typically recognize that certain populations of these species may, in fact, be hydrophytes - that is, plants growing in substrates subjected to frequent prolonged saturation. Verifying that these populations are hydrophytes requires a determination that most of the plants in question exhibit a morphological property known to form in hydrophytes or that undrained hydric soils are present, or both. Today, with increased appreciation of the role of wetlands in water quality enhancement, flood control, and other functions, accurate identification and delineation of these resources is vital to maintaining the wealth of wetland values for our society and future generations. 


\section{References}

Barbour, M. G., J . H. Burk, and W. K. Pitts. 1980. Terrestrial plant ecology. Menlo Park, CA: Benjamin/ Cummings Publishing.

Braun-Blanquet, J . 1932. Plant sociology. New York, NY: McGraw-Hill.

Cowardin, L. M., V. Carter, F. C. Golet, and E. T. LaRoe. 1979. Classification of wetlands and deepwater habitats of the United States. FWS/OBS-79/31. Washington, DC: U.S. Fish and Wildlife Service.

Daubenmire, R. F. 1947. Plant and environment: A textbook of plant autecology. New York, NY: J ohn Wiley and Sons.

Daubenmire, R. F. 1968. Plant communities: A textbook of plant synecology. New York, NY: Harper and Row.

Environmental Laboratory. 1987. Corps of Engineers wetland delineation manual. Technical Report Y-87-1. Vicksburg, MS: U.S. Army Engineer Waterways Experiment Station.

Federal Interagency Committee for Wetland Delineation. 1989. Federal manual for identifying and delineating jurisdictional wetlands. Cooperative technical publication. Washington, DC: U.S. Army Corps of Engineers, U.S. Environmental Protection Agency, U.S. Fish and Wildlife Service, and USDA Soil Conservation Service.

Lichvar, R., and J . Kartesz. 2009. North American digital flora: National Wetland Plant List, version 2.4.0. Hanover, NH: U.S. Army Corps of Engineers, Engineer Research and Development Center, Cold Regions Research and Engineering Laboratory, and Chapel Hill, NC: BONAP. https:// wetland_plants.usace.army.mil

Malone, K., and H. Williams. 2010. Growing season definition and use in wetland delineation. ERDC/ CRREL CR-10-3. Hanover, NH: U.S. Army Corps of Engineers, Engineer Research and Development Center, Cold Regions Research and Engineering Laboratory.

Reed, P. B. 1988. National list of plant species that occur in wetlands: 1988 national summary. Biol. Rep. 88(24). Washington, DC: U.S. Fish and Wildlife Service.

Sculthorpe, C. D. 1967. The biology of aquatic plants. London, England: Edward Arnold Publishers.

Sipple, W. S. 1988. Wetland identification and delineation manual. Volume I. Rationale, wetland parameters, and overview of jurisdictional approach. Revised interim final report. Washington, DC: U.S. Environmental Protection Agency, Office of Wetlands Protection. 
Tiner, R. W. 1988. Field guide to nontidal wetland identification. Cooperative publication. Annapolis, MD: Maryland Dept. of Natural Resources, and Newton Corner, MA: U.S. Fish and Wildlife Service.

Tiner, R. W. 1991. The concept of a hydrophyte for wetland identification. BioScience 41: 236- 247.

Tiner, R. W. 1993. Wetlands are ecotones-reality or myth? In Wetlands and ecotones: Studies on land-water interactions, ed. B. Gopal, A. Hillbricht-Ilkowska, and R. G. Wetzel, 1- 15. New Delhi, India: National Institute of Ecology and International Scientific Publications.

Tiner, R. W. 1999. Wetland indicators: A guide to wetland identification, delineation, classification, and mapping. Boca Raton, FL: Lewis Publishers, CRC Press.

Tiner, R. W. 2006. Lists of potential hydrophytes for the United States: A regional review and their use in wetland identification. Wetlands 26: 624-634.

USACE. 2010. Regional supplement to the Corps of Engineers Wetland Delineation Manual: Atlantic and Gulf Coastal Plain Region (Version 2.0). ERCD/ EL TR-1020. Vicksburg, MS: U.S. Army Corps of Engineers, Engineer Research and Development Center, Environmental Laboratory.

Warming, E. 1909. Oecology of plants. An introduction to the study of plantcommunities. (Updated English version of a 1896 text.) Oxford, England: Clarendon Press.

Weaver, J . E., and F. E. Clements. 1929. Plant ecology. New York, NY: McGraw-Hill. 


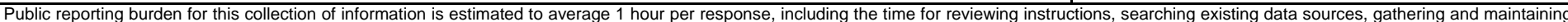

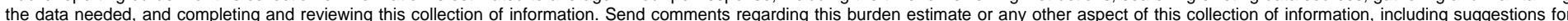

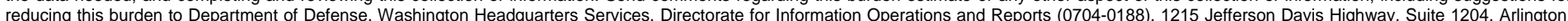

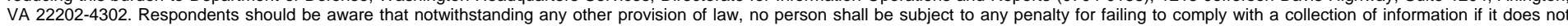
display a currently valid OMB control number. PLEASE DO NOT RETURN YOUR FORM TO THE ABOVE ADDRESS.

\begin{tabular}{l|l}
\hline 1. REPORT DATE (DD-MM-YYYY) & 2. REPORT TYPE \\
January 2012 & Contract Report \\
\hline
\end{tabular}

\section{TITLE AND SUBTITLE}

Defining Hydrophytes for Wetland Identification and Delineation

3. DATES COVERED (From - To)

5a. CONTRACT NUMBER

\section{Defing Hydrophytes for Wetland Identification and Delineation}

6. AUTHOR(S)

Ralph W. Tiner

er

2

7. PERFORMING ORGANIZATION NAME(S) AND ADDRESS(ES)

U.S. Army Engineer Research and Development Center

Cold Regions Research and Engineering Laboratory

72 Lyme Road

Hanover, NH 03755-1290

9. SPONSORING / MONITORING AGENCY NAME(S) AND ADDRESS(ES)

5b. GRANT NUMBER

5c. PROGRAM ELEMENT NUMBER

5d. PROJECT NUMBER

5e. TASK NUMBER

5f. WORK UNIT NUMBER

8. PERFORMING ORGANIZATION REPORT NUMBER

ERDC/ CRREL CR-12-1

10. SPONSOR/MONITOR'S ACRONYM(S)

11. SPONSOR/MONITOR'S REPORT NUMBER(S)

\section{DISTRIBUTION I AVAILABILITY STATEMENT}

Approved for public release; distribution is unlimited.

Available from NTIS, Springfield, Virginia 22161.

13. SUPPLEMENTARY NOTES

\section{ABSTRACT}

The presence of hydrophytic vegetation is an essential ingredient in the definition of wetlands. The National Technical Committee for Wetland Vegetation was, among other things, charged with reviewing the concept of a hydrophyte and constructing a definition that conforms with the use of hydrophytic vegetation for identifying wetlands whether regulated or not. This report reviews the term "hydrophyte," presents the proposed definition, and briefly discusses the use of hydrophytes for wetland identification and delineation.

\section{SUBJECT TERMS}

Hydrophytes Wetland delineation

Wetland identification

Wetland vegetation

\section{SECURITY CLASSIFICATION OF:}

a. REPORT

$\mathrm{U}$

b. ABSTRACT

$\mathrm{U}$

\begin{tabular}{c|c|}
$\begin{array}{c}\text { 17. LIMITATION } \\
\text { OF ABSTRACT }\end{array}$ & $\begin{array}{c}\text { 18. NUMBER } \\
\text { OF PAGES }\end{array}$ \\
U & 18 \\
\hline
\end{tabular}

19a. NAME OF RESPONSIBLE PERSON

19b. TELEPHONE NUMBER (include area code) 